\title{
KURA-KURA DALAM ARKEOLOGI DAN BIOLOGI DI INDONESIA
}

\author{
Oleh: H.S. Hardjasasmita*
}

Di Asia Tenggara, kura-kura mempunyai arti penting dalam bidang arkeologi dan biologi. Dalam bidang arkeologi, kura-kura mempunyai kedudukan tertentu, terbukti dengan adanya anggapan keramat atau meluhurkan beberapa kelompok kura-kura di kolam atau di sumber air, seperti di Kudus - Jawa Tengah, Kampung Talun dekat Madiun - Jawa Timur, (Delsman, 1951) dan di Gunung Kidu! Yogyakarta. Di kawasan lain di luar Indonesia, seperti di Penang - Malaysia. Bangkok - Thailand dan India (Schmidth dan Inger. 1954), kura-kura tertentu juga mendapat penghormatan yang sepadan dengan kedudukan yang penting seperti di Indonesia (Jawa). Kedudukan kura-kura yang lebih terrinci dan lebih jelas di dalam susunan kepercayaan dan budaya di Indonesia kiranya perlu mendapat perhatian yang lebih dalam dari para ahli budaya dan arkeologi.

Pada relief candi di Pulau Jawa, seperti di candi Borobudur, Panataran, Candi Bulus dan Candi Sukuh, citra kura-kura atau penyu terlukis sebagai figur yang mempunyai arti. Di Candi Borobudur misalnya. penyu (kura-kura) digambarkan sebagai penjelmaan dari Dewa Siwa (Steinmann. 1934). Demikian pula di Candi Sukuh, kura-kura sebagai penjaga gerbang. kiri dan kanan, menggambarkan bumi (Stutterheim 1930 Gambar 2) dan di Candi Bulus citra kura-kura dihubungkan dengan air dan kesuburan (Sukarto K. Atmodjo. 1983). Lebih jauh lagi ke masa lampau, beberapa lukisan gua di beberapa tempat di Indonesia terdapat lukisan yang diinterpretasikan sebagai gambar kura-kura (Kosasih, 1985). Apa arti gambar kura-kura di dalam gua itu sebenarnya masih harus diselidiki.

Jurusan Binlogi ITB dan PAI RAD Bandung.

Berkala Arkeologi VII (2) 
Tapi yang penting gambar kura-kura itu pasti mempunyai arti yang khusus

Bagaimana keadaan kura-kura. sebagai fauna Indonesia dan daerah sekitarnya. kiranya harus diteliti karena masih banyak yang belum diketahui. Bahwa ada beberapa kelompok masyarakat yang mengkeramatkan kura-kura, hal ini menunjukkan bahwa dahulu kurakura mempunyai kedudukan penting dan tersendiri, berkaitan dengan mitos dan keagamaan (Delsman, 1951).

Kura-kura dan penyu secara umum merupakan salah satu sumber daya hayati hewani. Jenis binatang tersebut bukan saja berfungsi sebagai sumber protein tapi juga beberapa bagian cangkangnya merupakaan bahan untuk berbagai kerajinan tangan, yang juga penting bagi industri rakyat. Berbagai macam hiasan dan alat-alat yang fungsionil. seperti sisir penyu, sendok penyu dan lain-lain dibuat dari "kulit" penyu. Masakan dari daging kura-kura atau penyu tidak asing lagi bagi beberapa orang atau masyarakat yang menyukainya, demikian pula telurnya (Hendrikson. 1961 dan Raffles, 1982).

Justru karena disukainya maka kelestarian kura-kura dan penyu terancam. Jawatan Pengawetan dan Perlindungan Alam (PPA) di Indonesia. bertindak tepat sekali untuk melindungi beberapa penyu dan kura-kura. karena kalau tidak. besar kemungkinan kura-kura dan penyu di Indonesia punah. Bila hal itu benar-benar terjadi anak cucu kita hanya dapat melihat kura-kưra dan penyu dari gambai dtau dan reliet candi saja.

\section{JENIS KURA-KURA DAN PENYU DI INDONESIA}

Dalam pengertian umum, kura-kura adalah hewan yang termasuk Ordo Chelonia, Kelas Reptilia, dan Filum Vertebrata (Rooij. 1915). Biasanya yang dinamakan kura-kura ialah berbagai jenis Chelonia yang hidup di darat dan di air tawar. sedangkan penyu adalah Chelonia yang hidup di laut atau di perairan laut. Secara 
keseluruhan Chelonia yang hidup di darat, air tawar maupun di laut, untuk mudahnya, disebut kura-kura.

Di Candi Borobudur kedua kelompok kura-kura (darat dan laut) digambarkan pada salah satu bagian reliefnya, yaitu bila kita interpretasikan air yang bergelombang itu laut atau lautan, dan yang tidak bergelombang ialah darat atau kolam.

Di Indonesia ada tiga jenis kura-kura laut atau penyu. Semuanya hidup di laut, dan ke darat hanya sekali-kali saja, misalnya untuk bertelur. Penyu biasanya mendarat di pantai yang berpasir dalam $(2-10 \mathrm{~m})$ untuk bertelur dan menimbun telurnya di pasir sampai menetas. Ketiga jenis kura-kura laut itu ialah: 1) Penyu hijau = Chelonia mydas, 2) Penyu sisik = Chelonia imbricata dan 3) Penyu belimbing $=$ Dermochelys coriacea. Ketiganya dari Familia: Chelonidae. Kehadiran ketiga penyu tersebut di pantai Indonesia tidak merata. Umumnya penyu hijau lebih sering didapatkan dari pada penyu lainnya di berbagai pantai berpasir di Kepulauan Indonesia.

Di Indonesia, kura-kura darat atau kura-kura, terdiri dari be berapa kelompok atau familia. Hanya satu kelompok yang benarbenar hidup di darat yaitu Familia Testudinidae. Lainnya umumnya hidup di rawa, sawah, kolam, sungai atau di tempat lain yang berair. Untuk mengetahui jenis dan nama kura-kura tersebut kiranya dapat diidentifikasi dengarı mengetahui ciri-cirinya dan dengan meng. gunakan kunci-nama.

\section{Ordo: Chelonia}

\section{Ciri-ciri umum:}

Tulang quadrate bersatu dengan tengkorak; tak dapat bergerak bergeser-geser. Tidak mempunyai gigi; lapisan zat tanduk membungkus rahang. Badan terbungkus oleh rumah tulang (shell). Rusuk dorsal berkepala satu; tidak ada sternum; lubang anal bulat atau berupa celah; mempunyai alat kopulatori tunggal. Opivarous; telur lonjong atau bundar; terbungkus cangkang relatif keras-kokoh (calcareous), atau lunak seperti kulit (leathery) (Loveridge, 1946). 


\section{KUACI KEPADA FAMILIA CHELONIA}

(Lihat gambar: 3 dan 4 untuk istilah taksonomi)

A. Rumah (shell) tertutup pelindung dari zat tanduk epidermal.

B. Lempeng pelindung pektoral (plastron) berhubungan langsung (incontact) dengan maginal.

C. Papan plastron 11 atau 12 buah, Emydidae \& Testudinidae.

CC.

CC. Papan plastron 13 buah ............... Chelyidae

BB. Lempeng pelindung pektoral terpisah lebar dari marginal,

D. Panjang ekor. $1 / 2 \times$ panjang rumah; plastron kecil, krusiform ........................ Chelydridae "Hanya terdapat di Irian Jaya".

DD. Panjang ekor kurang dari $1 / 2 \times$ panjang rumah, kaki berbentuk pendayung, terdapat 1 atau 2 cakar........ Cheloniidae

Ân. Kumah tanpa lempeng pelindung zat tanduk,

E. Anggota gerak dengan jari-jari yang jelas; ekor 3 buah: Tryonychidae

EE. Anggota gerak lebar pipih dengan 2 cakar, atau tanpa cakar.

F. Tidạk ada cákar ................ Dermochelyidae FF.

FF. Cakar, dua buah ............... Carettochelyidae 
KUNCI KEPADA BEBERAPA KURA-KURA FAMILIA EMYDIDAE DI INDONESIA

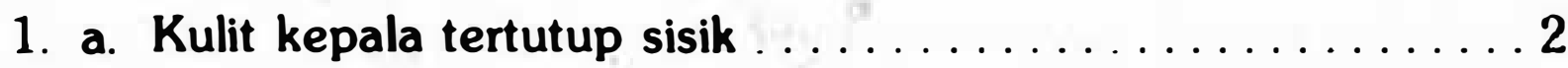

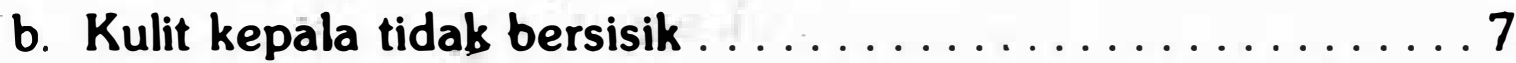

2. a. Rahang bergigi, pada yang muda geriginya halus ....... 3

b. Rahang rata; anggota gerak depan dengan 5 cakar ......4

3. a. Kaki depan dengan 4 cakar; kadang-kadang mereka pergi ke muara sungai; Sebaran: Sumatra ......... Batagur basca. "Kura-kura cakar 4".

b. Kaki depan dengan $\mathbf{5}$ cakar; Sebaran: Kalimantan, Filipina, Callagur borneensis.

"Kura-kura rahang gerigi".

4. a. 1 atau 2 alur pada langit-langit (mulut) (palate); Sebaran: Sumatra, Kalimantan ............... Orlitia borneensis. "Kura-kura Kalimantan".

b. Tak ada alur pada langit-langit mulut . . . . . . . . . . 5

5. a. Carapace dengan $6-7$ lempeng tulang vertebral

Notochelys platynota.

"Kura-kura berbintik".

b. Carapace dengan 5 tulang vertebral . . . . . . . . . 6

6. a. Mata merupakan pusat bintik (spot) kuning bintik lain di daerah pelipis; carapace dengan alur geger yang menonjol, alur lateral hanya pada yang muda dan tidak jelas; Sebaran: Sumatra, Jawa, Kalimantan ................... Bellia crassicolis. "Kura-kura hitam".

b. Garis kuning dari nostril melalui atas mata ke leher, satu lagi di bawah mata; carapace dengan alur vertebral yang menonjol dan alur lateral; Sebaran: Sumatra, Kalimantan, Jawa ....... Damonia subtrijuga.

"Kura-kura alur 3". 
7. a. Bagian depan dan belakang plastron dapat digerakan, rumah dapat ditutup sempurna; Sebaran: dari Sumatra sampai Seram Cyclemys amboinensis. Kura-kura batok, "Kuya Batok".

b. Bagian depan plastron tidak dapat ditutup ...........8 8

8. a. Sebagian plastron dihubungkan dengan carapace dengan ligament, bagian posterior plastron hanya dapat digerakan sedikit; Sebaran: Sumatra, Kalimantan, Filipina ................ Cyclemys dentata "Kura-kura batok gerigi".

b. Plastron bersatu dengan carapace dengan suture, plastron tidak dapat digerakkan ..................... 9

9. a. Carapace dengan 3 alur geger (ridges); pinggiran plastron yang hitam mempunyai bagian yang terang; pangkal ekor mempunyai tonjolan seperti duri; Sebaran: Sumatra, Kalimantan, Filipina .................... Geomyda spengleri. "Kura-kura perut hitam".

b. Carapace dengan 1 alur, atau sama sekali tidak ada; ekor tanpa tonjolan seperti duri

Carapace denigan alur vertebral; plastron agak sempit, tanpa lekukan (notch), semua pelat plastron ada garis "radier" coklat pada dasar kuning; Sebaran: Sumatra, Kalimantan .......... ............................. Geoemyda spinosa. "Kura-kura duri".

\section{KURA-KURA DARAT}

(Tortois)

Hanya ada dua jenis kura-kura darat di Indonesia. Sebarannya tidak meliputi Irian Jaya. Kura-kura darat dapat dikenali dengan kunci seperti berikut ini:

1. Rumah bagian atas (plastron) mempunyai nuchal dan dua papan supracaudal (lihat gambar rumah kura-kura); Sebarannya: Suma- 
tra, Kalimantan dan daratan Asia

Testudo emiys.

"Kura-kura darat coklat".

2. Atap rumah tanpa nuchal dan hanya mempunyai papan supra caudal; Sebarannya: Sulawesi, Halmahera dan Maluku

Testudo forsteni.

"Kura-kura darat Maluku".

\section{KUNCI KEPADA KURA-KURA LUNAK}

(Soft shell Turtles)

1. a. Kepala relatif sangat besar ......... Dogania subplana. "lobi-lobi MALAYA"

b. Kepala sedang, atau relatif kecil; . . . . . . . . . . . 2

2. a. Sebarannya Timor, Formosa dan Jepang .... Trionyx sinensis. "lobi-lobi TIMOR"

b. Sebarannya Sumatra dan Kalimantan, juga di Jawa ......... Trionyx cartilagineus "lobi-lobi biasa, bulus".

Sejauh ini, kura-kura mempunyai arti yang penting di dalam budaya masyarakat Indonesia. Selain ada kaitannya dengan kepercayaan dan arkeologi, kura-kura termasuk penyu, penting bagi masyarakat Indonesia karena juga merupakan sumber daya hayati hewani.

Rekaman kura-kura darat maupun laut di masa lampau didapatkan di Candi Borobudur, Candi Prambanan dan Candi Sukuh. Demikian pula rekaman kura-kura terdapat di gua di Indonesia sebagai lukisan gua. Dari segi jenisnya di Indonesia sedikitnya terdapat; Dua jenis kura-kura darat sejati*; tujuh jenis kura-kura air tawar*; tiga jenis kura-kura lunak“. dan tiga jenis kura-kura laut atau penyu ${ }^{* \cdots *}$ 


\section{DAFTAR KURA-KURA DI INDONESIA}

Kura-kura darat*

Testudo emys - kura-kura darat coklat

Testudo for'steni - kura-kura darat Maluku

Kura-kura air tawar**

Batagur basca - kura-kura cakar empat

Bellia crassicolis - kura-kura hitam

Damonia subtrijuga - kura-kura alur tiga

Cyclemy's amboinensis - kura-kura batok

Cyclemys dentata - kura-kura batok gerigi

Geoemida spengleri - kura-kura perut hitam

Orlitia borneensis - kura-kura Kalimantan

Kura-kura lunak $\cdots$

Dogania subplana - lobi-lobi Malaya

Trionyx sinensis - bulus Timor

Trionyx cartilagineus - bulus biasa.

Kura-kura laut (penyu) $)^{\cdots \cdot . *}$

Chelonia mydas - penyu hijau

Chelonia imbricata - penyu sisik

Dermochelys coriacea - penyu belimbing. 


\section{DAFTAR PUSTAKA}

BRONGERSMA, L.D. 1958. The animal world of the Netherlands New Guinea. Groningen: J.B. Woters, Nederland.

DELSMAN, H.C. Dierenleven in Indonesia. Bandung: N.V. Uitgeverij W. van hoeve, Indonesia.

FONTEIN, J; R. SOEKMONO dan S. SULEIMAN; 1972. Kesenian Indonesia Purba. New York: Franklin Book Programs, Inc.

GOIN. C.J. dan OB. GOIN; Introduction to Herpetologi San Fransisco: W.H Freeman Co., A.S.

HENDRIKSON, JR; 1961. Conservation investigation on Malayan turtle. Nature Conservation in Western Malaysia 1961. Malayan Nature Journal. Spec. Issue, 21st.

KOSASIH S.A; 1986. Studi komparatif tentang lukisan gua prasejarah di kawasan Asia Tenggara. Pertemuan Ilmiah Arkeologi IV, (IIb). Proyek Penelitian Purbakala Jakarta. Dep. P dan K, 379 - 394.

LOVERIDG E.A; 1946. Reptiles of the Pacific world New York: The Macmillan Co. A.S.

RAFFLES, T.H; 1982 (cetak ulang). The History of Java. (Jilid I) Kuala Lumpur: Oxford University Press, Malaysia.

ROOIJ. N. de; 1915. The Reptiles of the Indo-Australian Archipelago. Leiden: E.J. Brill Nederland.

SCHMIDT K.P. dan R.F. INGER; 1957. Living Reptiles of the world Garden City, New York: Hanover House, A.S

STEINMANN, A; Welke dieren vindt men op de Boroboedoer en op engkele Hindu-Javaansche bouwwerken afgebeeld? De Tropische Natuur. Jilid 23, No. 5 , Hal 86 - 96.

STUTTERHEIM, W.F; 1930. Gids voor de oudheden van Soekoeh en Tjeta. Soerakarta: De Bliksem, Indonesia.

SUKARTO K ATMODJO, M.M; 1983. Punden Cemoro Bulus di lereng barat Gunung Lawu. Pertemuan Ilmiah Arkeologi III, Ciloto, 23-28 Mei 1983: 12 halaman 

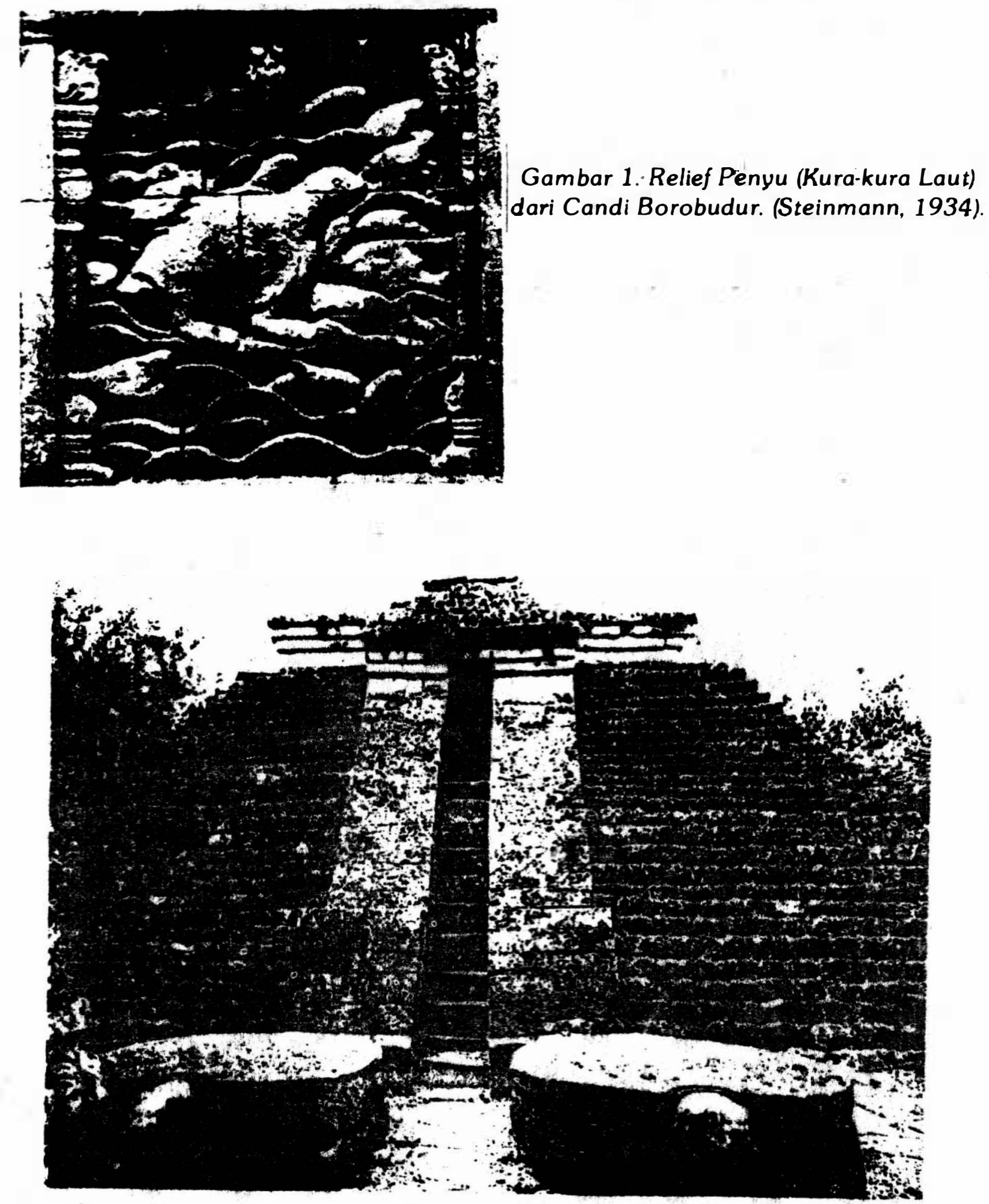

Gambar 2. Patung kura-kura di depan Candi Sukuh, Lereng Gunung Lawu. Jawa Timur. Dari Fontein, J.. R. Soekmono dan S. Suleiman: 1972. 

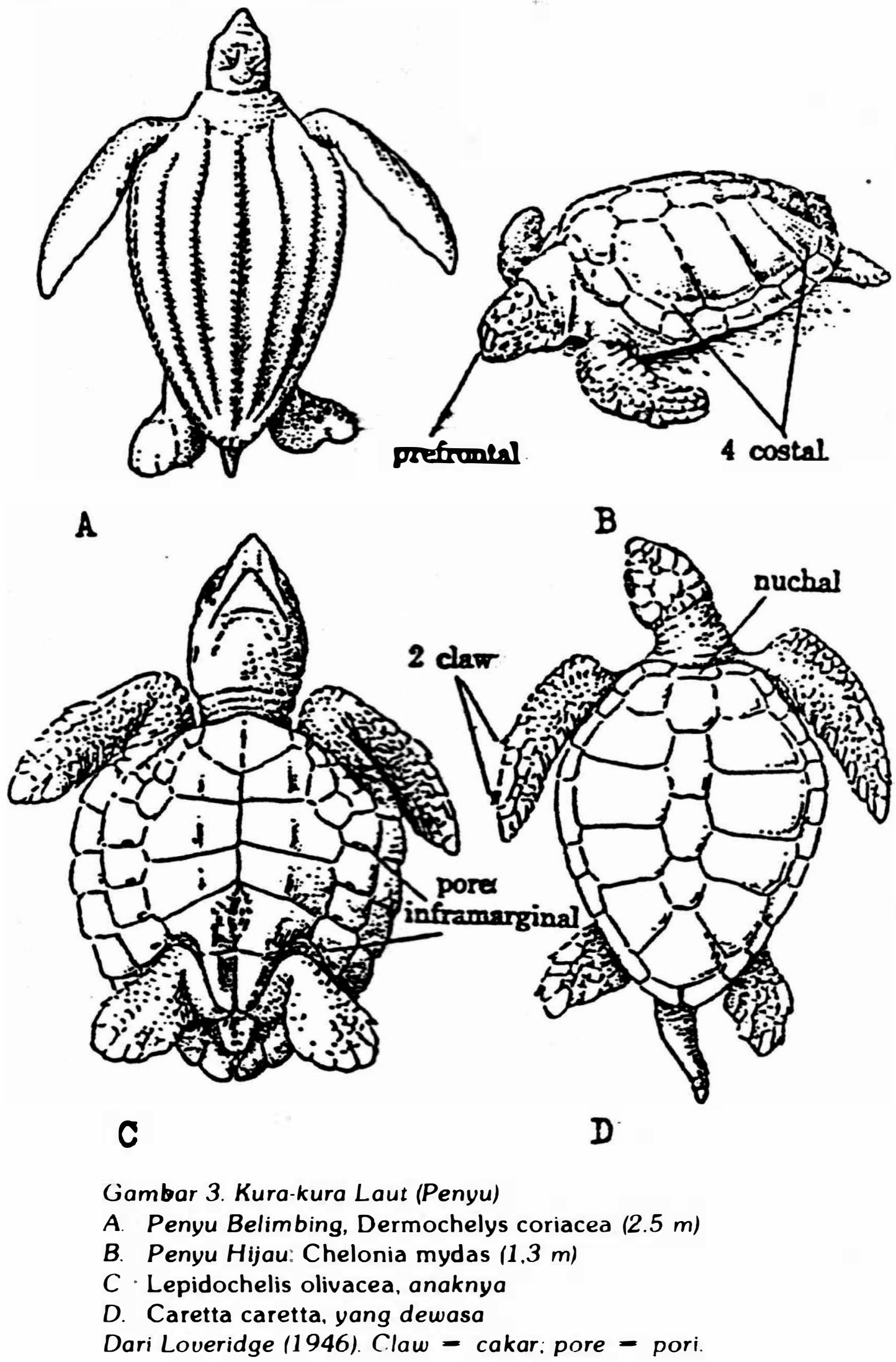

Berkala Arkeologi VII (2) 

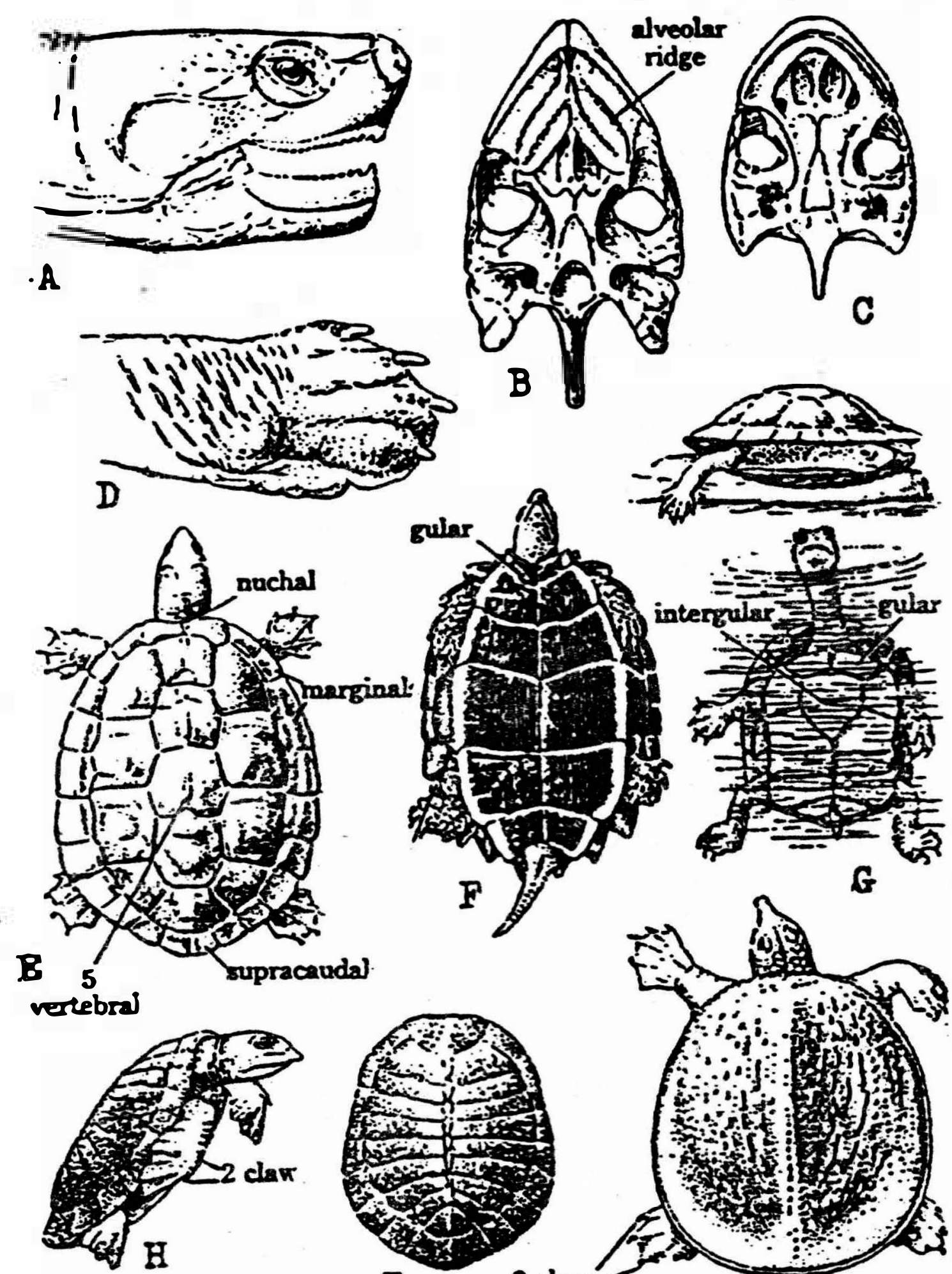


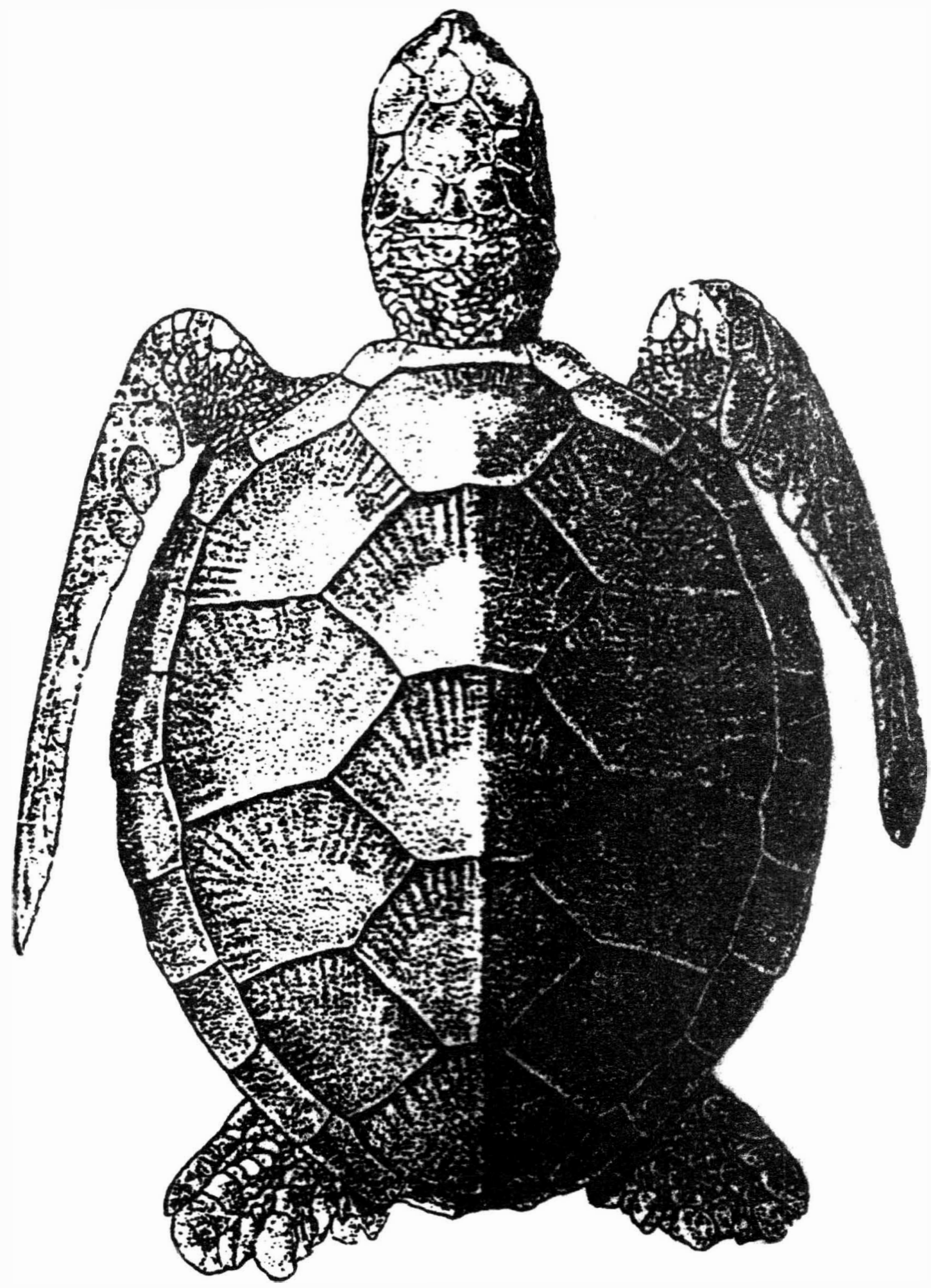

Gambar 5. Penyu Hijau, Chelonia mydas Dari Brongersma (1958).

Berkala Arkeologi VII (2) 


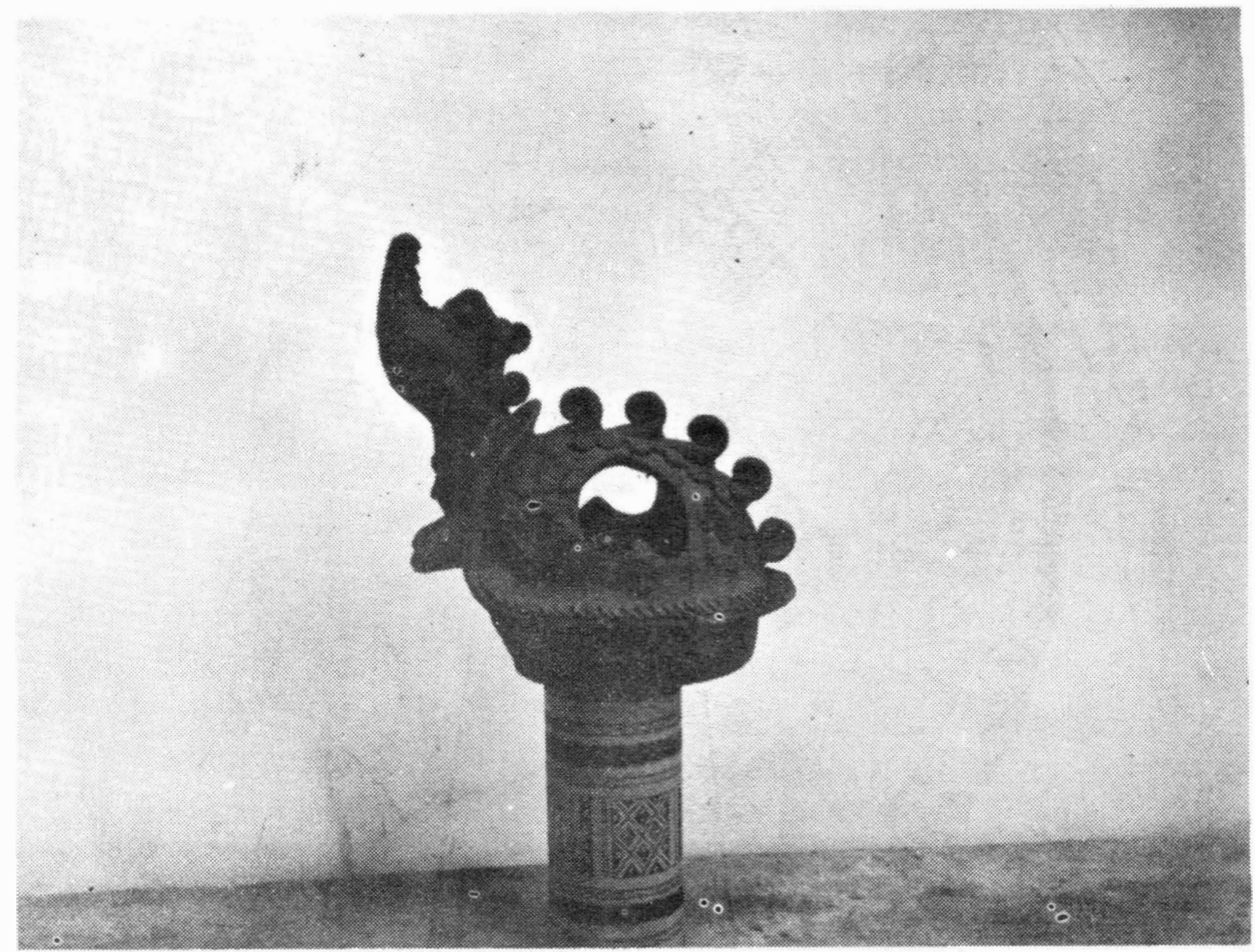

Gambar 6. Kura-kuro dari tanah liat, Kasongan, Yogyakarta Selatan (Foto parlis). 